\title{
ÁLVARO DE LUNA (1840), DE ANTONIO GIL Y ZÁRATE, ANTE LA PRENSA DE SU TIEMPO
}

\author{
MaRía del CARMEN RodríGuez LoREnZO \\ Universidad de Vigo
}

\section{RESUMEN}

En el presente trabajo llevo a cabo el análisis de las reseñas aparecidas en los periódicos de la época sobre Don Álvaro de Luna (1840) de Antonio Gil y Zárate. Gracias a este estudio, podemos saber cuál fue la repercusión de la obra, cómo fue acogida por el público, cómo fue la representación de los actores, los días que estuvo en escena, qué se le criticó y qué se le alabó al autor... teniendo siempre presente el interés que suscitó el estreno de esta obra después del escándalo que había supuesto Carlos II el hechizado (1837).

PALABRAS ClAVE: Álvaro de Luna, Gil y Zárate, drama histórico, drama romántico

\section{Abstract}

In the present work I carry out the analysis of the reviews appeared in the newspapers of the epoch on Don Álvaro de Luna (1840) of Antonio Gil y Zárate. Thanks to this study, we can know which was the repercussion of the work, how it was received by the public, how it was the representation of the actors, the days that it was in scene, what criticized him and that boasted to the author ... bearing in mind always the interest that provoked the premiere of this work after the scandal that one supposed of previous work of the author: Carlos II el hechizado (1837).

KEY wORDS: Álvaro de Luna, Gil y Zárate, historical drama, romantic drama

El drama Don Álvaro de Luna (1840), de Antonio Gil y Zárate, lleva a escena en el madrileño teatro del Príncipe las circunstancias históricas y personales que rodearon el ajusticiamiento del condestable de don Juan in de Castilla ${ }^{1}$. Tanto la época, como el propio maestre de Santiago, habían sido ya objeto de atención por parte del autor. Dos

Recibido: 04-08-2017 / Aceptado: 15-09-2017

${ }^{1}$ Este trabajo se inserta en el ámbito de investigación del proyecto código FFI2015-64107-P (MINECOFEDER, UE). 
años antes había publicado una semblanza titulada El condestable don Álvaro de Luna, así como un relato, El paso honroso, ambos de $1838^{2}$, en los que muestra su interés por la corte castellana de la primera mitad del siglo xv. Por esos años, además, Gil prepara su Manual de Literatura, en el que podemos leer interesantes referencias a la literatura y a la época de Juan II, de la que se destacan los argumentos caballerescos, las canciones y los romances, las funciones cortesanas organizadas para diversión y deleite de nobles y caballeros, así como obras concretas del marqués de Santillana (Comedieta de Ponza) o del marqués de Villena (comedia alegórica con la Justicia, la Verdad, la Paz y la Misericordia como interlocutoras) $)^{3}$.

Tampoco es la primera vez que el personaje de Luna llama la atención de los dramaturgos románticos durante los últimos años de la primera guerra carlista, ya que, a finales de 1838, con pocos meses de diferencia, se representan en Valencia y en Valladolid, respectivamente, Don Álvaro de Luna, de José María Bonilla y Los cortesanos de don Juan II, de Jerónimo Morán, piezas de claro contenido político que posteriormente se reestrenan en Madrid y en diferentes capitales españolas ${ }^{4}$. Con todo, la notoriedad pública e intelectual de Gil y Zárate convierte su pieza en la de mayor trascendencia de entre las que abordan la temática del condestable en su tiempo.

La obra da cuenta de la caída del don Álvaro tras la pérdida de la confianza que en él venía depositando don Juan II desde niño, derivada tanto de su mal obrar como de las intrigas de sus adversarios políticos. El de Luna es, al inicio del drama, un hombre con enorme influencia en la corte y en la voluntad de rey, pero con no menos poderosos enemigos, cuya animadversión se ha ido ganando a lo largo de los años, como Juan Pacheco. Villena, que ambiciona el poder y todo lo que representa el maestre, convence a Vivero para que le ayude a acabar con el condestable. Engatusado por las promesas del marqués, el contador accede. Tras el rapto de Elvira, hija en la ficción dramática de don Álvaro, por Pacheco, el condestable descubre que Vivero se ha aliado con su enemigo y ha traicionado su confianza. Furioso, Luna ordena que don Alfonso sea arrojado desde lo alto de una torre, a la que ha sido atraído con engaños.

\footnotetext{
${ }^{2}$ A. Gil y Zárate, «El paso honroso», Semanario Pintoresco Español, 121, (22 de julio 1838), pp. 639-642. A. Gil y Zárate, «El condestable don Álvaro de Luna», Semanario Pintoresco Español, 123, (5 de agosto 1838), pp. 655-658.

${ }^{3}$ A. Gil y Zárate, Manual de literatura. Tomos I y II, Madrid, Boix, 1844. Los escritores más relevantes del tiempo de Juan II (Santillana, Mena...) a los que se refiere Gil aparecen en su drama como personajes que componen y recitan versos que sintetizan argumentos o sirven de transición ente las acciones de tipo personal y la política.

${ }^{4}$ M. Ribao Pereira, «Una relectura romántica de la corte: Los cortesanos de don Juan II, de J. Morán» en J. M. González Herrán et al., eds., La historia en la literatura del siglo XIX, Barcelona, Universitat de Barcelona, 2017, pp. 651-660 y M. Ceide Rodríguez, «El Romanticismo y la recuperación de la materia medieval: el caso de J. Morán», en R. Hernández Arias, G. Rivera Rodríguez, S. Cuba López y D. Pérez Álvarez (eds.), Nuevas perspectivas literarias y culturales (I CIJIELC), Vigo, MACC-ELICIN, 2016.
} 
El rey manda prender a Luna, pero anhela que este pida clemencia. El condestable se niega y acepta su destino. Ya en el patíbulo, regala a su paje Morales el único bien que posee: el anillo que don Juan le había regalado con la promesa de concederle cualquier merced con solo mostrárselo. Mediante esta prenda Elvira consigue el perdón real, pero Villena ha adelantado el reloj de la torre y el indulto llega en el momento en que cae, finalmente, la cabeza de don Álvaro.

La puesta en escena de este argumento, que, como he mencionado anteriormente, no es nuevo en las tablas, fue recibida con inusual expectación. Apenas tres años antes, en 1837, Gil y Zárate había provocado uno de los grandes escándalos de la temporada con la representación de Carlos II el hechizado, redactado a juicio de R. de Mesonero en «algún momento de satánica tentación» ${ }^{5}$, y en 1839 se había estrenado en la sociedad El Liceo Rosamunda, con la que parecía haber «emprendido de nuevo una senda más sensata» ${ }^{6}$. No es extraño, por tanto, que su drama, en cinco actos y en verso, ambientado en la corte de don Juan II, en la que los románticos encontraron argumentos históricos de enorme pertinencia para la reflexión, en clave liberal, sobre su propio tiempo, fuese objeto de múltiples reseñas de signo bien distinto y de agudas precisiones de tipo literario, político, histórico y espectacular que justifican la atención que voy a prestarles en estas páginas.

El drama, que se representa durante doce días prácticamente consecutivos en febrero de 1840, suscita una intensa e inmediata reacción crítica ${ }^{7}$. Tras el estreno El Corresponsal ${ }^{8}$ orienta la atención de sus lectores hacia la figura de don Álvaro:

Conocida es la historia de este famoso valido que, después de más de treinta años de una privanza sin ejemplo, concluyó su brillante carrera con una sangrienta

\footnotetext{
${ }^{5}$ R. de Mesonero Romanos, Memorias de un setentón, Madrid, Ábaco, 1982, p. 360. Sobre las reacciones que este drama suscita, B. Rodríguez Gutiérrez, «De retractaciones y falsificaciones. Antonio Gil y Zárate y Carlos II», en R. Gutiérrez Sebastián y B. Rodríguez Gutiérrez (eds.), Desde la platea. Estudios sobre el teatro decimonónico, Santander, PubliCan, 2010, pp. 35-76 y B. Rodríguez Gutiérrez, «Para una revisión del teatro de Antonio Gil y Zárate», Siglo Diecinueve (Literatura Hispánica), 17 (2001), pp. 7-32.

${ }^{6}$ El juicio pertenece a A. F. Schack en su Historia de la literatura y del arte dramático en España, E. de Mier (trad.), Madrid, Tello, 1885-1887.

${ }^{7}$ El drama se lleva a escena los días 1-4, 7-8, 11-16, tal y como coinciden en señalar los avisos de los diferentes diarios de la capital: Anónimo, «Diversiones públicas», Diario de Avisos de Madrid, 1772, 1774, 1775 (1840), p. 4; Anónimo, «Folletín», Diario de Avisos de Madrid, 1779 (1840), p. 1; Anónimo, «Diversiones públicas», Diario de Avisos de Madrid, 1785 (1840), p. 3; Anónimo, «Diversiones públicas», Diario de Avisos de Madrid, 1776, 1777 (1840), p. 4; Anónimo, «Diversiones públicas», El Corresponsal, 246, 247 (1840), p. 4; Anónimo, «Diversiones públicas», El Corresponsal, 248 (1840), p. 3; Anónimo, «Anuncios», El Corresponsal, 251 (1840), p. 4; Anónimo, «Diversiones públicas», El Corresponsal, 259 (1840), p. 4; Anónimo, «Teatros», El Piloto, 333, 334, 336, 344, 345, 347, 348 (1840), p. 4; Anónimo, «Anuncios», El Eco del Comercio, 2105, 2114 (1840), p. 4. Los días 5 y 6 se suspenden las representaciones por descanso del actor principal, García Luna, tal y como señalan los anónimos redactores de El Piloto (338 [1840], p. 4) o El Eco del Comercio (2016, 2017 [1840], p. 4).
}

${ }^{8}$ Anónimo, «Diversiones públicas», El Corresponsal, n 248, 3 de febrero (1840), p. 3. 
catástrofe, perdiendo la vida en un cadalso9.

En opinión del anónimo autor de la reseña, la importancia de la representación radica en su protagonista, al que considera uno de los personajes más grandes de la historia de España. Deja a juicio de los ilustrados lectores de la publicación decidir si Zárate ha trasladado bien o no los últimos días del condestable a las tablas, si bien sugiere falta de fuerza dramática en la pintura del maestre en el desenlace, a la hora de afrontar tan resignadamente su muerte como se muestra en la obra.

Dos días después El Corresponsal publica una nueva reseña ${ }^{10}$ que, firmada por Coello y Quesada, alaba una vez más al personaje histórico que protagoniza la obra, cuyo apogeo y caída es de esos pasajes de la historia de nuestro país - afirma- que no se pueden olvidar. Hace especial hincapié en su carácter de «huérfano desvalido» que gobernará durante treinta años él solo en Castilla y que dejará a su muerte gestas extraordinarias como la victoria de Olmedo. Resulta significativo que, frente a las lecturas habituales de los textos ambientados en tiempos del rey Juan II, que establecen un paralelismo claro entre el monarca e Isabel II, sea en este caso Luna el elemento de comparación, acaso porque, como reitera tanto el drama como la historiografía sobre el tema, haya sido don Álvaro el verdadero monarca de Castilla - antes incluso de su privanza - hasta su ajusticiamiento en 1453. Desde este presupuesto, el mensaje de El Corresponsal en 1840, recién terminada la primera guerra carlista, parece claro: ningún gobierno, ni el de un poderoso valido como don Álvaro, ni el de la legítima Isabel II, está a salvo de las nocivas consecuencias de las conspiraciones nobiliarias y cortesanas. La revolución del 68 confirmará los tempranos temores que la lectura del drama parece haber suscitado en Coello y Quesada.

Otra de las cuestiones relevantes en la reseña de El Corresponsal es la adscripción del drama a la escuela romántica o a la neoclásica. Como apuntan Alborg y Peers ${ }^{11}$, Gil y Zárate se adscribe a la primera en su exigencia de libertad formal para tratar los asuntos históricos. Del neoclasicismo destacaría

por su innato amor al orden, por su preocupación por la forma, por su inclinación a crear tipos más que individuos, por su respeto (no siempre a prueba de las conveniencias) de las unidades de lugar y tiempo, y por su reverencia casi supersticiosa a la unidad de acción ${ }^{12}$.

\footnotetext{
${ }^{9}$ Idem.

${ }^{10}$ D. Coello y Quesada, «Don Álvaro de Luna, drama en cinco actos y en verso, su autor D. Antonio Gil y Zárate», El Corresponsal, n 250, 5 de febrero (1840), pp. 1-3.

${ }^{11}$ J. L. Alborg, Historia de la literatura española IV. El Romanticismo, Madrid, Gredos, 1986, p. 630. E. A. Peers, Historia del movimiento romántico español II, Madrid, Gredos, 1973, p. 179.
}

12 J. L. Alborg, ob. cit., p. 630. 
Coello no se muestra interesado en dirimir la cuestión, sino que constata el hecho de que el drama de Gil es un texto histórico que no respeta las reglas del clasicismo escénico, ya que la acción dura veinticuatro días y no veinticuatro horas, las escenas más importantes se desarrollan en el palacio y en la cárcel, en vez de en una sala y en un jardín, y las acciones particulares y públicas se condicionan mutuamente en su desarrollo.

Este planteamiento responde perfectamente a la concepción teatral que el propio Gil y Zárate expone en sus textos teóricos. La elección de los espacios responde a su respeto por la verosimilitud como principio esencial para atraer y mantener la atención del espectador:

Si la acción dramática ha de interesarnos y complacernos, es forzoso que sea verosímil; es decir, que esté dispuesta de tal modo, que nos cause completa ilusión, y la creamos verdadera ${ }^{13}$.

De ahí que si Gil quiere representar el tormento que sufrió el condestable y ser próximo a la historia, deba representar las escenas en decorados fieles a los espacios en que tales hechos sucedieron, con independencia de que la puesta en escena del cadalso pueda ser considerada de mal gusto.

En cuanto a que la acción dure veinticuatro días y no veinticuatro horas, Gil considera lícito quebrantar la unidad temporal mientras las obras sean verosímiles, pues

lo verdaderamente inverosímil es que en un solo día ocurran sucesos que necesitan muchos en el orden natural, y en este defecto han incurrido con frecuencia los que han pretendido observar con exactitud la regla de las veinticuatro horas ${ }^{14}$.

En cuanto a la fidelidad histórica, recalca Coello que el autor ha seleccionado para su drama tan solo una vertiente histórica, la más general, añadiendo otras para completar la trama dramática, como sustituir al «hijo herido» ${ }^{15}$ de don Álvaro por Destúñiga, quien recibirá la mano de Elvira - que no es un personaje histórico ${ }^{16}$-, para «endulzar las penas de un padre desgraciado» ${ }^{17}$. Reprocha a Zárate que ya en el primer acto olvide su condición de dramaturgo y se «presente como poeta lírico», cuidando

\footnotetext{
${ }^{13}$ A. Gil y Zárate, Manual de Literatura, 1ª parte, ob. cit., p. 249.

${ }^{14}$ Ibidem, p. 274.

${ }^{15}$ D. Coello y Quesada, art. cit. p. 2.

${ }^{16}$ Las verdaderas hijas de don Álvaro de Luna se llamaban: María de Luna, hija extramatrimonial, y María de Luna y Pimentel, fruto del segundo matrimonio con Juana Pimentel. Cabe destacar que la primera mujer de don Álvaro de Luna se llamaba Elvira y que quizás Zárate cogiese de ahí el nombre de la hija para su obra.
}

${ }^{17}$ D. Coello y Quesada, art. cit., p. 3. 
más la belleza de los versos que la tensión dramática, lo que explicaría «la mancha terrible que la escena última de este acto hace caer sobra la memoria de D. Álvaro de Luna ${ }^{18}$, o que en el segundo quiera desdibujar algunos aspectos de la vida del condestable para no afearle ante la opinión pública convirtiéndole, sin embargo, en un hipócrita ${ }^{19}$.

Alaba, sin embargo, el segundo acto, el mejor de la obra a su juicio, resaltando del mismo su última escena y estas palabras de Luna:
A vosotros
me basta veros rendidos;
y en prueba de que no os temo
os perdono compasivo ${ }^{20}$.

Gusta, asimismo, que Zárate apenas se haya detenido en el perfil de Juan Pacheco y que no le haya dado mayor protagonismo en la obra, aun cuando sean parte de su parlamento algunos de los mejores versos de la obra, los «versos lindísimos» de la tercera escena del primer acto:

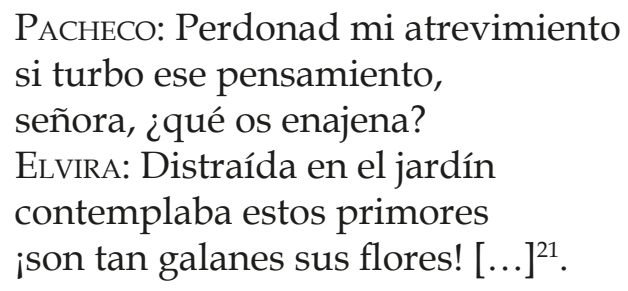

Coello resalta también que Zárate haya recreado en el cuarto acto un certamen literario en el que participan los poetas más importantes del tiempo, como el marqués de Santillana y Juan de Mena, que recitan ante la corte sus poesías, y que deje entrever tras aquellos hombres entregados a las armas en guerras contra los árabes y otros reyes de la península, a los hombres de letras que se rendían al «encanto y dulzuras de la poesía que crecía por momentos» ${ }^{22}$.

Desagrada, no obstante, al crítico de El Corresponsal el abrazo del rey y don Álvaro poco antes de la muerte de este, que se haya alargado la agonía de Luna cuando de todos era sabida su suerte y que la joven Elvira tenga que ver a su padre ir hacia el cadalso sin poder gritarle que ella tenía su salvación en la mano, hechos todos ellos que Coello considera inverosímiles. Para el dramaturgo, estos lances de sufrimiento

\footnotetext{
${ }^{18}$ Idem.

${ }^{19}$ Ibidem, p. 2.

${ }^{20}$ Ibidem, p. 3.

${ }^{21} \mathrm{Idem}$.

${ }^{22}$ Idem. 
deben quedar fuera del teatro, ya que en él «una palabra enérgica vale más que los lentos y penosos esfuerzos del poeta» ${ }^{23}$.

Aunque lo que resalta el artículo a propósito de la obra es

un conocimiento profundo de la historia, un pincel admirable para trazar los caracteres, un interés, que si alguna vez desmaya un tanto, crece luego por instantes, una versificación valiente y atrevida ${ }^{24}$,

no se obvia la crítica a su autor por caracterizar a don Álvaro con la hipocresía, la vileza y la miseria de las que Zárate lo ha dotado. El condestable era un hombre con un carácter dominante y orgulloso que inexplicablemente el dramaturgo - buen conocedor del personaje- presenta resignado a su destino, prematuramente envejecido y débil.

En el ámbito de la puesta en escena, aunque la opinión general sobre los actores principales (Luna, Lombía, Alberá y Teodora Lamadrid) es buena, se les sugieren pequeños cambios que redundarían en una mayor efectividad dramática de sus respectivos personajes.

En cuanto a los decorados, Coello destaca la belleza del principal del acto III:

El teatro representa una galería o parte de corredor que da la vuelta al patio grande de un castillo. Por los arcos de esta galería se ve lo restante del patio, y en el fondo una de las torres que debe ser practicable, alcanzándose también a ver la parte del cielo. A los dos lados del proscenio habrá igualmente otras torres. La de la derecha del actor tiene una puerta pequeña que se supone dar a un pasadizo o escalera estrecha que conduce al pie de la misma torre. La de la izquierda tiene una gran puerta gótica que conduce a habitaciones interiores. Más allá de estas torres hasta la barandilla del corredor, el paso está expedito, de suerte que se puede recorrer libremente toda la galería e ir por ella a las demás partes del edificio. Es de noche, y la escena está alumbrada por una lámpara que cuelga del techo ${ }^{25}$.

El público, satisfecho en términos generales, pidió la salida de Gil y Zárate al escenario al término de la representación. Su mérito y reconocimiento literario resultan incuestionables:

[...] el sr. Gil y Zárate debe tener la conciencia de su mérito y al no poseerla, la tienen sus admiradores que son cuantos asisten a la representación de sus obras [...] Largo por demás es este artículo. Creemos lo merecía el cuadro de la vida de un grande hombre trazado por el pincel de uno de los más distinguidos literatos de nuestra España ${ }^{26}$.

\footnotetext{
${ }^{23}$ Ibidem, p. 2.

${ }^{24}$ Idem.

${ }^{25}$ A. Gil y Zárate, Don Álvaro de Luna, ob. cit., p. 54.

${ }^{26}$ D. Coello y Quesada, art. cit., p. 3.
} 
Don Álvaro de Luna es, en definitiva, una obra digna de ser vista, «pero lo es mil veces más de ser leída y estudiada ${ }^{27}$, en cuyo caso el lector extraerá más conclusiones y entenderá mejor el sentido y los aspectos políticos que se encierran en ella, relacionados con la proclama liberal que encarna Gil en tiempos de la primera guerra carlista.

Casi simultáneamente aparece en $E l$ Entreacto ${ }^{28}$ un nuevo artículo sobre el drama, en el que Miguel Agustín Príncipe afirma, rotundo, que la pieza carece de intensidad teatral y de atención por los temas que más interesan en la época (el amor, las aventuras, las leyendas...), pese a lo cual se trata de una de las obras más importantes del teatro contemporáneo y una de las más logradas de su autor. Tras el estreno de Blanca de Borbón, Rosamunda o Carlos II el hechizado, Gil y Zárate habría tenido que solventar no pocos obstáculos para lograr la puesta en escena de la nueva pieza, por lo que Príncipe se permite aconsejar a los críticos más severos (Coello y Quesada entre ellos) una mayor condescendencia.

La labor del dramaturgo resulta más encomiable aun cuando se consideran los obstáculos que ha debido vencer a la hora de llevar a escena el conflicto que conduce a Luna al cadalso. El primero de ellos es la propia dificultad de ofrecer al público un tema muy conocido de forma novedosa, aspecto este que, una vez resuelto, se convierte en un excelente resorte para captar el interés del receptor. El segundo consiste en adaptar adecuadamente el personaje histórico al teatro, respetando en todo momento el modelo medieval. El tercero pasa por hacer del personaje de don Juan un hombre digno a pesar de sus errores y el cuarto por respetar los hechos históricos enlazándonos con una intriga personal perfectamente imbricada en los anteriores, así como por respetar el final de Luna y mostrarlo tal cual aconteció, minimizando en todos los casos la incidencia de la temática amorosa, acaso la que más interesa en la época, y reduciéndola al ámbito de lo imprescindible, esto es, al de los esquemáticos amores entre Destúñiga y Elvira.

Según Príncipe, cuando Zárate publique la segunda edición de su obra debe eliminar algunos versos que ralentizan la representación, ya que -a su juicio- los personajes hablan mucho:

y no rara vez repiten ideas emitidas anteriormente. El llanto de don Álvaro cuando pide a Pacheco que le devuelva la hija que le acaba de robar, y las expresiones que le dirige con este motivo, merecen también meditarse en la segunda edición: llore en buenhora el condestable, esto hacer honor a su corazón; pero no olvidemos que

\footnotetext{
${ }^{27}$ Idem.

${ }^{28}$ M. A. Príncipe, «Don Álvaro de Luna; drama original, histórico, en cinco actos y en verso, de don Antonio Gil y Zárate», El Entreacto, no 11, 6 de febrero (1840), pp. 1-2.
} 
es el condestable quien llora, que es don Álvaro quien suplica ${ }^{29}$.

Recuerdan estas palabras los juicios expuestos en El Corresponsal sobre el carácter de don Álvaro:

su grandeza, su carácter firme y altanero, su valor para resistir los embates de tantos grandes coligados que procuraban derribarle de su alto puesto, la humillación a que logró reducirlos, y por último, su ascendiente sobre el rey a quien dominaba imperiosamente, al propio tiempo que con sus esfuerzos sostenía el trono y sacaba de su abatimiento el poder monárquico ${ }^{30}$.

Como vemos, ambos críticos coinciden en la consideración del fuerte carácter de Luna y en la inverosimilitud de su reacción ante el rapto de su hija, ya que lo que se espera de él es que haga uso de su coraje y valentía, de ahí que tanto Coello como Príncipe sugieran a Gil y Zárate modificar un tanto el perfil del protagonista en una próxima revisión del drama. La segunda edición de la pieza, en 1850, constata que el escritor no tomó en consideración ninguna de estas indicaciones.

A propósito de la actuación de los actores, afirma El Entreacto que resultó lo suficientemente esmerada para poder gustar y complacer tanto al público como al mismo autor, pese a lo cual la compañía no ha sabido estar a la altura de interpretar un drama de la categoría del presente. Luna, Lombía y López, todos ellos interpretando a personajes principales, habrían sido los más destacados. La reacción del público, que reclamó entre aplausos al autor, ratifica el éxito de la pieza.

Como conclusión, y tal y como ocurría en la reseña de El Corresponsal, Príncipe recomienda leer el drama para saborear en él las bellezas que la representación pasa por alto y reconocer los valores más literarios que escénicos de un texto excelente.

La reseña de El Eco del Comercio ${ }^{31}$ del 7 de febrero considera el drama en su doble dimensión: «composición poética» $\mathrm{y}$ "obra histórica» ${ }^{32}$. Y aunque reconoce su calidad, superior a la mayoría de las piezas de la época, el texto y su autor son duramente enjuiciados. Tras un breve resumen del argumento, al que el crítico califica de «mitad histórico, mitad fabuloso» ${ }^{33}$ por la invención de Elvira y los hechos a ella vinculados, se destaca la inexacta caracterización de la época que se deriva de contraponer una sociedad «grave y dogmática» a otra «frívola y caballeresca», donde Juan de Mena

\footnotetext{
${ }^{29}$ Ibidem, p. 1.

${ }^{30}$ Anónimo, «Diversiones públicas», El Corresponsal, nº 248, 3 de febrero (1840), p. 3.

${ }_{31}$ Anónimo, «Don Álvaro de Luna, Drama nuevo original por don Antonio Gil y Zárate», El Eco del Comercio, ${ }^{\circ}$ 2108, 7 de febrero (1840), pp. 1-2.

${ }^{32}$ Ibidem, p. 1.

${ }^{33} \mathrm{Idem}$.
} 
«florecía» junto a don Álvaro de Luna y las trovas del marqués de Santillana» ${ }^{34}$. Se critica la ausencia, en el drama, de aspectos muy conocidos — como la consideración generalizada de Villena como hechicero- y de formulaciones políticas esenciales, como el reconocimiento del principio de unidad monárquica, vigente en la época pese a la flaqueza de carácter de don Juan II $^{35}$.

Estructuralmente, el crítico de El Eco del Comercio valora negativamente la independencia de las acciones principales del drama, es decir, la caída y muerte de don Álvaro y los amores de Elvira con Destúñiga, circunstancia que incide en una falta de suspense y en la consiguiente pérdida de interés por parte del público. Por otra parte, la ambición sin límites del «cortesano envejecido» en que se ha convertido don Álvaro no suscita la empatía del espectador, como tampoco parece que los afectos de Elvira resulten teatralmente efectivos, por parecer más propios de novela que de drama.

Otras críticas tienen que ver con la salida y la entrada en escena de personajes sin causa conocida, con el injustificado rapto de Elvira o con la inverosimilitud del quinto acto en su totalidad, considerado por el anónimo autor de la reseña como el peor del drama, debido a la pintura de la terrible humillación del rey -que acude a rogar a su condestable que le pida perdón-y la del orgullo de Luna, que se niega a ello, en una inversión de papeles del todo inmotivada.

Tampoco la caracterización de los demás personajes le parece adecuada: tanto Elvira como Destúñiga son personajes propios de los siglos XVI o XVII, sumisa ella a la voluntad del padre pese a saber que obedeciéndole va a ser infeliz, caballero enamorado el joven, dispuesto a cualquier tipo de heroísmo por su fidelidad a Luna.

La actuación de los actores es otro de los aspectos negativos que destaca El Eco, a excepción de Teodora Lamadrid:

Luna representó el papel del condestable como si estuviese haciendo el del barbero en la piececita Retascón, barbero y comadrón ${ }^{36}$; y el señor Lombía se acordó también hartas veces durante la representación de la tía Marizápalos ${ }^{37}$.

Sí merece elogios el estilo, incluso la versificación:

Del estilo diremos para ser justos que aunque algo metafórico es en general bueno, y la versificación robusta y armoniosa, abundando en hermosos pensamientos

\footnotetext{
${ }^{34}$ Idem.

35 «Mucho más podríamos decir sobre este particular si no temiésemos excedernos de los estrechos límites de un folletín» (Ibidem, p. 2).

${ }^{36}$ Comedia en un acto, de Eugène Scribe, adaptada por Ventura de la Vega.

${ }^{37}$ Anónimo, «Don Álvaro de Luna, Drama nuevo original por don Antonio Gil y Zárate», art. cit., p. 2. 
expresados con bastante filosofía ${ }^{38}$.

Las palabras finales de este artículo son bastante duras, ya que se ruega a los futuros literatos que no tomen como ejemplo estas obras de autores bien reconocidos que, sin embargo, son «extravíos de mal gusto»» indignas de ser imitadas ${ }^{39}$. Resuenan tras estos juicios los ecos de la polémica suscitada pocos años antes por Carlos II el hechizado, duramente atacado por los sectores católicos ${ }^{40}$.

Además de incluir puntual noticia sobre las sucesivas representaciones de la pieza, el Diario de Avisos de Madrid ${ }^{41}$ incorpora el día 8 de febrero una breve crítica de la misma, que considera a Don Álvaro de Luna una obra de mérito literario más que regular, pero no un drama de gran efecto, de ahí que su acogida no haya sido todo lo buena que se esperaba. Pese a la categoría de su autor -afirma-, el respeto por la historia, la caracterización de los personajes y la acción, el tema que aborda -excesivamente árido- y la versificación, en ocasiones desaliñada ${ }^{42}$, no conmueven al público, ávido de emociones, al que le interesa mucho más el argumento amoroso que el político. Se trata de un texto, en definitiva, más apto para ser leído que para ser llevado a escena, un drama que debe tener «todo aficionado en su estantería» ${ }^{43}$.

Dos meses después de la representación, El Corresponsal ${ }^{44}$ publica una comparación de Don Álvaro de Luna con Rosmunda ${ }^{45}$ y Carlos II el hechizado ${ }^{46}$. La conclusión, en la línea expuesta por el Diario de Avisos, es el elogio de la segunda, debido a que se trata de «una tragedia amorosa», que complace al espectador más que «introducir la política en el teatro» ${ }^{47}$ :

Hemos dicho que Rosmunda es la más bella de las composiciones del sr. Gil y Zárate, y ya que antes no nos fue dado hablar de ella, diremos el porqué de nuestro pobre parecer. No somos de aquellos a quienes gusta ver introducida la política en el teatro: nos encanta, nos halaga más la tragedia amorosa, ideal de Racine, que la filosofía política de Voltaire; nos conmueven más los versos de la Atala que los de Mahomet, nos agrada, nos halagan más los tiernos, los amorosos versos de

\footnotetext{
${ }^{38} \mathrm{Idem}$.

${ }^{39}$ Idem.

${ }^{40}$ B. Rodríguez Gutiérrez, «Para una revisión del teatro de Antonio Gil y Zárate» en Revista siglo XIX, $\mathrm{n}^{\circ}$ 17 (2011), pp. 7-32.

${ }^{41}$ Anónimo, «Folletín», Diario de Avisos de Madrid, no 1779, 8 de febrero (1840), pp. 1-2.

${ }^{42}$ Ibidem, p. 2.

${ }^{43}$ Idem.

${ }^{44}$ D. Coello y Quesada, «Teatros», El Corresponsal, n 330, 26 de abril (1840) pp. 2-3.

${ }^{45}$ A. Gil y Zárate, Rosmunda, Madrid, Yenes, 1839.

${ }^{46}$ A. Gil y Zárate, Carlos II el hechizado, Madrid, Repullés, 1837.

${ }^{47}$ D. Coello y Quesada, «Teatros», art. cit., pp. 2-3.
} 
Rosmunda que los de Carlos II y de D. Álvaro ${ }^{48}$.

Una de las más extensas y detalladas críticas coetáneas del drama es la que Gervasio Gironella expone en la Revista de Madrid ${ }^{49}$, cuyo punto de partida es la dificultad manifiesta de enjuiciar la obra de uno de los autores más reconocidos del momento, de talento y buen hacer dramático, además de amigo. Zárate consigue mantener el interés del espectador durante los cinco actos de la pieza, a pesar de ser un drama de asunto solo político y de menor interés teatral que Carlos II el hechizado: a diferencia del drama de 1837, el de 1840 no toca la sensibilidad del público, carece de escenas amorosas y tiernas y la ambición y la política no llegan a conmover al receptor.

Gironella redacta una breve presentación de don Álvaro de Luna como personaje histórico, a quien Gil ha sabido caracterizar con acierto:

En el turbulento e infeliz reinado de Don Juan el II, se presenta el personaje colosal de Don Álvaro de Luna, sosteniendo la monarquía en medio de las revueltas y conspiraciones de una grandeza ambiciosa y desmandada, y sucumbiendo y sufriendo el último suplicio por efecto de las intrigas de los mismos grandes, que despojándole del afecto del monarca, y haciendo rodar su cabeza ante un patíbulo, prepararon las escandalosas escenas de Ávila, en el reinado siguiente, en que don Enrique iv fue públicamente y con escándalo depuesto en estatua de su dignidad real ${ }^{50}$.

Sin embargo, en los tres últimos actos Luna aparece en escena únicamente ocupado en intrigas cortesanas, falto de la elevación que merece por posición y valimiento. El marqués de Villena, su enemigo, se perfila en la obra como un ser de escaso carácter, por lo que la lucha por el poder entre ellos dos no es, como debería, una lucha entre iguales ${ }^{51}$. Opina Gironella que, teniendo en cuenta la relevancia histórica de Villena en la caída de don Álvaro y el hecho de que ocupe su cargo, una más cuidada caracterización del marqués habría redundado en un mayor ensalzamiento del condestable.

El drama podría haber tenido más interés si se hubiese incluido en su trama a la reina ${ }^{52}$, enemiga manifiesta del protagonista, o si don Juan il hubiese valorado la inconsistencia de la acusación que un solo hombre, Villena, arroja sobre Luna al

\footnotetext{
${ }^{48}$ Ibidem, p. 2.

${ }^{49}$ G. Gironella, «Don Álvaro de Luna. Drama en cinco actos, por D. Antonio Gil y Zárate», Revista de Madrid, Segunda serie, tomo II (1840), pp. 258-266.

${ }^{50}$ Ibidem, p. 259.

${ }^{51}$ Idem.

${ }^{52}$ Isabel de Portugal fue enemiga declarada de don Álvaro de Luna debido a la influencia que este ejercía sobre su marido, Juan II, tal y como recogen J. M. de Flores, Crónica de don Álvaro de Luna, condestable de los reinos de Castilla y León, maestre y administrador de la orden y caballería de Santiago, Madrid, Sancha, 1784 y J. de Mariana, Historia General de España, Madrid, Gaspar y Roig, 1852-1853.
} 
señalarle como asesino del contador. Y pese a estas debilidades del enredo dramático, Zárate consigue "presentar un drama con solo una figura en todo el cuadro, pero colosal e interesante» ${ }^{53}$, sobre todo en los dos últimos actos.

El suplicio de don Álvaro ocurre en Valladolid y el dramaturgo, que sí ha dado cuenta de ello en una acotación,

El teatro representa una gran sala de la casa que sirve de prisión a don Álvaro. En el fondo una ancha ventana gótica que, abriéndose, deja ver la plaza de Valladolid. $[\ldots]^{54}$,

nada dice del traslado del protagonista desde Burgos hasta Valladolid, lo que puede llevar a confusión a los espectadores y sugerir que el quinto acto se desarrolla también en Burgos. Cierto es - apunta Gironella-que este hecho es conocido por todos, pero podría haberse evitado el malentendido de un modo muy simple, añadiendo «unos cuantos versos ${ }^{55}$. También componiendo sentidos y hermosos versos ${ }^{56}$ podría evitarse la infantil la actuación del rey, que se obstina en no perdonar a don Álvaro por no pedir este clemencia al monarca ${ }^{57}$.

Se critica también que Zárate haya concentrado su maestría en perfilar al personaje principal y haya descuidado el atrezo, el movimiento y la vida de la obra, así como la caracterización de los antagonistas, cuya grandeza habría dotado de mayor interés al conflicto dramático.

Gironella está seguro de que los receptores verán con gusto la obra y leerán con placer los grandes versos que contiene. Acaso haya quienes critiquen en ellos el uso de retruécanos o juegos de palabras, sobre todo en el primer acto, como por ejemplo en estas palabras de Pacheco a Vivero:

A la sombra del de Luna

Castilla medrar os vio;

mas si esa luna se eclipsa

decid, ¿qué será de vos? ${ }^{58}$

La voluntad del dramaturgo habría sido recrear el lenguaje de la época, que resulta ser una fabla figurada, en ocasiones excesivamente recargada de sentencias y

\footnotetext{
${ }^{53}$ G. Gironella, «Don Álvaro de Luna. Drama en cinco actos, por D. Antonio Gil y Zárate», art. cit., p. 259.

${ }^{54}$ A. Gil y Zárate, Don Álvaro de Luna, ob. cit., p. 91.

${ }^{55}$ G. Gironella, «Don Álvaro de Luna. Drama en cinco actos, por D. Antonio Gil y Zárate», art. cit., p. 260.

${ }^{56} \mathrm{Ibidem}, \mathrm{p} .261$.

${ }^{57}$ Coincide en este aspecto con la crítica de Coello y Quesada, que subrayaba la improcedencia de este desenlace.

${ }^{58}$ G. Gironella, «Don Álvaro de Luna. Drama en cinco actos, por D. Antonio Gil y Zárate», art. cit., p. 261.
} 
máximas filosóficas de las que Gil hace uso aun cuando no corresponde.

El artículo finaliza con la felicitación al autor, al que se anima a seguir dando a la escena obras de este calibre, si bien ni la ejecución de los actores ni el estado de la sala han favorecido el éxito de Don Álvaro de Luna ${ }^{59}$.

Dos años más tarde, Manuel García Barzanallana analiza la producción teatral de Gil y Zárate hasta 1842 en Revista de España y del Extranjero ${ }^{60}$, comparando al dramaturgo con Lope o Calderón, a quienes menciona Gil en 1841, en su Teatro antiguo y moderno, al mostrarse partidario de un teatro que combinase la tragedia de los Siglos de Oro, el clasicismo y el romanticismo.

En la crítica concreta que hace de Don Álvaro de Luna, Barzanallana afirma que hay errores en el drama que le han restado interés, como la lentitud en la trama, la falta de explicación convincente de los planes que urden los antagonistas, la demorada atención a las costumbres de la España de la Edad Media y la elección del personaje del siglo Xv que más le convenía a Zárate, sin atender a otros matices que contribuirían a la intriga e interés de la pieza. También opina que hubiese sido deseable una mayor y más activa participación de don Juan en el drama, ya que tras los primeros actos el personaje se convierte en una presencia inmóvil ${ }^{61}$. Aunque el principio de la obra es realmente dramático, su conclusión es débil, debido a la acumulación de hechos y a la lentitud de la acción. Gil y Zárate no habría acertado en el desenlace:

El principio del $\mathrm{v}$ acto es muy dramático, pero la conclusión es débil, porque pasan demasiadas cosas y se camina muy despacio; y cuando se quiere dar el giro, que da el señor Gil, al final de su drama, creemos, que debe verificarse todo como de un golpe, y con sorpresa extraordinaria del espectador ${ }^{62}$.

Además de estas reseñas, son numerosas, las noticias breves sobre la representación que aparecen en El Corresponsal, El Correo de Madrid, El Piloto, El Eco del Comercio, Diario de Avisos de Madrid, El Guardia Nacional... En todas ellas se destaca, de modo casi tópico, la brillante sinfonía que da principio al drama, los aplausos que merece, la participación del actor Luna con papel protagonista, que

la sociedad dramática ha procurado adornar la producción que se anuncia con el

\footnotetext{
${ }^{59}$ A juicio de Gironella, solo la ejecución del actor Luna ha estado a la altura de las circunstancias. Sobre los aspectos formales del teatro del Príncipe y su estado en esta temporada, M. Ribao Pereira, «Vicisitudes empresariales de los teatros de La Cruz y el Príncipe en el Madrid de la regencia (8341840)», Boletín de la Biblioteca de Menéndez Pelayo (1898), pp. 155-178.

${ }^{60}$ M. García Barzanallana «Juicio crítico de los dramas de don Antonio Gil y Zárate», Revista de España y del Extranjero, Tomo II (1842), pp. 203-235.

${ }^{61}$ Ibidem, p. 205.

${ }^{62}$ Idem.
} 
aparato escénico que requiere y presentarla con la mayor brillantez, estrenándose en el tercer acto una decoración pintada por D. Francisco Lucini63.

así como la venta del texto impreso «a 8 reales en las librerías de Escamilla calle de Carretas y de Cuesta frente a las covachuelas, donde se hayan las demás obras dramáticas de este autor» ${ }^{64}$.

Como podemos observar, la reacción crítica que suscita el drama es diversa. Mientras El Corresponsal valora la transmisión de las características del condestable y de sus grandes hazañas, Barzanallana en Revista de España y del Extranjero considera excesiva la importancia que se le da a don Álvaro, cuya presencia anula por completo la personalidad del rey. Coincide este con Coello y Quesada en la consideración negativa del último acto, significativamente del desenlace. Del mismo modo, la crítica de El Diario de Avisos de Madrid echa en falta en esos «extravíos de mal gusto» que se criticaban en El Eco del Comercio. Y pese a las sugerencias de mejora de Príncipe, su valoración es claramente más positiva que la de los reseñistas previos, en la misma línea de Gironella.

Según El Corresponsal la obra fue muy aplaudida por el público, que incluso reclamó la presencia de Gil y Zárate en las tablas, pero Diario de Avisos de Madrid explica que el drama no ha suscitado interés entre los espectadores.

En cuanto al estilo, la mezcla de versos, la tendencia de los personajes a extenderse en sus parlamentos o incluso la redundancia de los mismos son aspectos criticados en El Entreacto y motivo de elogio en El Eco del Comercio y en Revista de Madrid.

La mayoría de las críticas, a favor o en contra, toman en consideración los mismos aspectos: la caracterización de don Álvaro, la adecuación o inadecuación del drama a la historia medieval, la ausencia de una verdadera trama amorosa, la invención de personajes, el decorado, el lenguaje, el metro, la tensión dramática, la puesta en escena de los actores... Ni siquiera en este último aspecto hubo unanimidad, ya que la general admiración por el actor Luna no impide que tanto él como Lombía sean objeto de burla en las páginas de El Eco del Comercio.

La multiplicidad y divergencia de las respuestas críticas que suscita el drama de Gil y Zárate manifiesta, en definitiva, la relevancia, trascendencia y alcance de Don Álvaro de Luna, que se concibe y se concreta escénicamente, como buen producto romántico, para agitar conciencias y sacudir voluntades. Las reseñas a las que acabo de referirme son buena prueba de ello.

\footnotetext{
${ }^{63}$ Anónimo, «Anuncios», El Corresponsal, nº 251, 6 de febrero (1840), p. 4.

${ }^{64}$ Anónimo, «Diversiones públicas», El Corresponsal, n 246, 1 de febrero (1840), p. 4.
} 


\section{BibLIOGRAFÍA}

Alborg, J. L., Historia de la Literatura IV. El Romanticismo, Madrid, Gredos, 1980.

AnÓNIMO, «Literatura y Bellas Artes», El Correo Nacional, nº 773, 29 de febrero (1840), p. 4.

, «Diversiones públicas», El Corresponsal, n² 246, 1 de febrero (1840), p. 4.

, «Diversiones públicas», El Corresponsal, n 247, 2 de febrero (1840), p. 4.

, «Anuncios». El Corresponsal, n ${ }^{\circ}$ 248, 3 de febrero (1840), p. 4.

, «Anuncios», El Corresponsal, n ${ }^{\circ}$ 251, 6 de febrero (1840), p. 4.

, «Diversiones públicas», El Corresponsal, n 259, 14 de febrero (1840), p. 4.

, «Don Álvaro de Luna, drama nuevo original por don Antonio Gil y Zárate», El Eco del Comercio, n ${ }^{\circ}$ 2108, 7 de febrero (1840), pp. 1-2.

, «Anuncios», El Eco del Comercio, n 2105, 4 de febrero (1840), p. 4.

, «Teatro del Príncipe», El Eco del Comercio, no 2106, 5 de febrero (1840), p. 4.

, «Anuncios», El Eco del Comercio, no 2107, 6 de febrero (1840), p. 4.

, «Teatro del Príncipe», El Eco del Comercio, no 2114, 13 de febrero (1840), p. 4.

, «Teatros», El Piloto, no 333, 1 de febrero (1840), p. 4.

, «Teatros», El Piloto, $\mathrm{n}^{\circ} 334,2$ de febrero (1840), p. 4.

, «Teatros», El Piloto, $\mathrm{n}^{\circ} 336,4$ de febrero (1840), p. 4.

, «Teatros», El Piloto, $\mathrm{n}^{\circ} 338,6$ de febrero (1840), p. 4.

, «Teatros», El Piloto, no 344, 12 de febrero (1840), p. 4.

, «Teatros», El Piloto, n ${ }^{\circ}$ 345, 13 de febrero (1840), p. 4.

, «Teatros», El Piloto, no 347, 15 de febrero (1840), p. 4

, «Teatros», El Piloto, n ${ }^{\circ}$ 348, 16 de febrero (1840), p. 4.

, «Anuncio», El Piloto, n 350, 18 de febrero (1840), p. 4.

, «Diversiones públicas», Diario de Avisos de Madrid, $\mathrm{n}^{\circ} 1772,1$ de febrero (1840), p. 3.

, «Diversiones públicas», Diario de Avisos de Madrid, n 1773, 2 de febrero (1840), p. 3 .

, «Diversiones públicas», Diario de Avisos de Madrid, n 1774, 3 de febrero (1840), p. 4.

, «Diversiones públicas», Diario de Avisos de Madrid, n 1775, 4 de febrero (1840), p. 3 .

«Diversiones públicas», Diario de Avisos de Madrid, nº 1776, 5 de febrero (1840), p. 4.

, «Diversiones públicas», Diario de Avisos de Madrid, n 1777, 6 de febrero (1840), p. 4.

, «Folletín», Diario de Avisos de Madrid, no 1779, 8 de febrero (1840), pp. 1-2. 
, «Diversiones públicas», Diario de Avisos de Madrid, n 1785, 14 de febrero (1840), p. 3 .

, «Diversiones públicas», Diario de Avisos de Madrid, n 1786, 15 de febrero (1840), p. 3.

Ceide Rodríguez, M., «El Romanticismo y la recuperación de la materia medieval: el caso de J. Morán», en R. Hernández Arias, G. Rivera Rodríguez, S. Cuba López y D. Pérez Álvarez (eds.), Nuevas perspectivas literarias y culturales (I CIJIELC), Vigo, MACC-ELICIN, 2016.

Coello y Quesada, D., «Don Álvaro de luna, drama en cinco actos y en verso, su autor D. Antonio Gil y Zárate», El Corresponsal, n 330, 26 de abril (1840), pp. 1-3.

García Barzanallana, M., «Juicio crítico de los dramas de Don Antonio Gil y Zárate», Revista de España y del Extranjero», Tomo II, 15 de junio (1840), pp. 203-235.

Gil y Zárate, A., Carlos il el hechizado, Madrid, Repullés, 1837.

, Don Álvaro de Luna, Madrid, Yenes, 1840.

, Manual de Literatura, $1^{a}$ parte, Madrid, Boix, 1843.

, Rosamunda, Madrid, Yenes, 1839.

Gironella, G., «Don Álvaro de Luna, drama en cinco actos, por D. Antonio Gil y Zárate», Revista de Madrid, tomo II (1839), pp. 258-266.

Mariana, J. de, Historia general de España, Madrid, Gaspar y Roig, 1852-1853.

Mesonero Romanos, R. de, Memorias de un setentón, Madrid, Ábaco, 1982.

PeErs, E. A., Historia del movimiento Romántico español II, Madrid, Gredos, 1973.

Príncipe, M. A., «Don Álvaro de Luna, drama original, histórico, en cinco actos y en verso, de don Antonio Gil y Zárate», El Entreacto, no 11, 6 de febrero (1840), pp. 1-2.

Ribao Pereira, M., «Vicisitudes empresariales de los teatros de La cruz y el Príncipe en el Madrid de la regencia (1834-1840)», Boletín de la Biblioteca de Menéndez Pelayo (1998), pp. 155-178.

, «Poderosos y tiranos en la primera parte de El zapatero y el rey», Anales de Literatura Española, n 18 (2005), pp. 303-316.

, «Una relectura romántica de la corte: Los cortesanos de don Juan II, de J. Morán» en J. M. González Herrán et al., eds., La historia en la literatura del siglo XIX, Barcelona, Universitat de Barcelona, 2017, pp. 651-660.

Rodríguez Gutiérrez, B., «Para una revisión del teatro de Antonio Gil y Zárate», Siglo Diecinueve (Literatura Hispánica), 17 (2001), pp. 7-32.

, «De retractaciones y falsificaciones. Antonio Gil y Zárate y Carlos II», en R. Gutiérrez Sebastián y B. Rodríguez Gutiérrez (eds.), Desde la platea. Estudios sobre el teatro decimonónico, Santander, PubliCan, 2010, pp. 35-76.

ScHACK, A. F., Historia de la literatura y del arte dramático en España, E. de Mier (trad.), Madrid, Tello, 1885-1887. 